\title{
Seroprevalence of HCV markers among HIV infected patients from Curitiba and metropolitan region
}

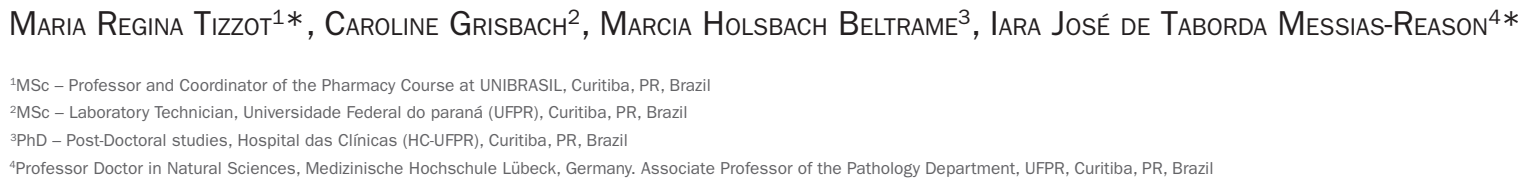

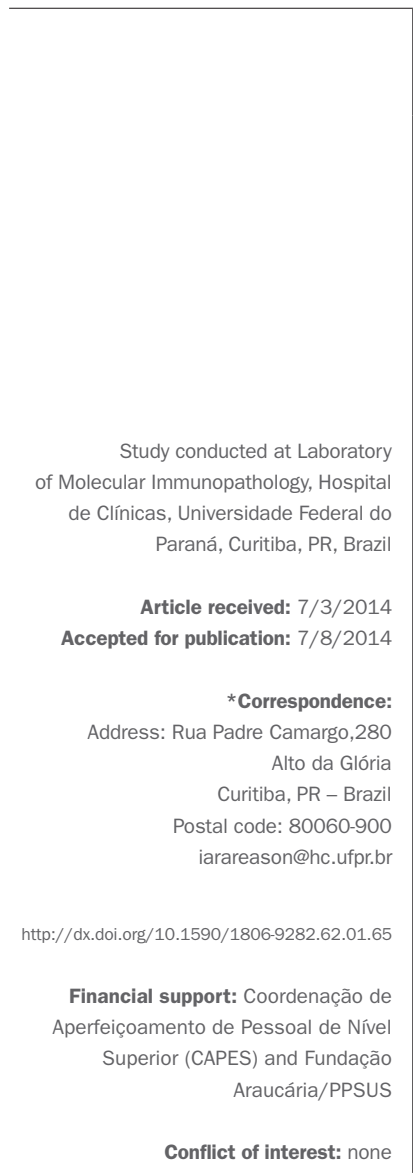

\section{SUMmARY}

Objective: to determine the prevalence and epidemiological factors associated with hepatitis (HCV) coinfection in human immunodeficiency virus (HIV) patients from Curitiba and the metropolitan region.

Methods: a study with $303 \mathrm{HIV}+$ patients, mean age 41.2 years (18-73); 50.5\% men, followed at the Hospital de Clínicas, Universidade Federal do Paraná, between April 2008 and March 2009. Clinical and epidemiological data were obtained through questionnaires and retrospective analysis of medical records. Anti-HCV antibodies were detected by chemiluminescence immunoassay.

Results: a total of $12.9 \%$ of HIV+ patients were positive for anti-HCV antibodies, $64.1 \%$ were men and $35.9 \%$ women, with mean age of 44.5 years (24-66). The frequency of HCV among men was $16.7 \%$ and among women $9.1 \%(\mathrm{p}=0.06)$. HCV prevalence was associated to HIV infection when compared to the general population $\left(\mathrm{p}<10^{-6}, \mathrm{OR}=100.4 ; 95 \mathrm{CI}=13.7-734.9\right)$. The parenteral route of transmission was the most frequent among coinfected patients (46.1\%), and the sexual transmission among HIV+/HCV- $(71.8 \%)(\mathrm{p}=0.02, \mathrm{OR}=0.2 ; 95 \mathrm{CI}=0.1-0.7)$. The frequency of intravenous drug users was higher among the coinfected patients $(61.5 \%)$ compared to the non coinfected $(12.6 \%)\left(\mathrm{p}^{<10^{-6}}, \mathrm{OR}=11.1 ; 95 \mathrm{CI}=4.5-27.7\right)$. Conclusion: the prevalence of coinfection with $\mathrm{HCV}$ in $\mathrm{HIV}+$ patients is $12.9 \%$, 88 times higher than in the general population in Curitiba. The most frequent route of transmission in the coinfected patients is parenteral, but the sexual route is also representative (34.6\%).

Keywords: HIV, acquired immunodeficiency syndrome, coinfection, hepatitis C.

\section{INTRODUCTION}

Infection with the human immunodeficiency virus (HIV), which causes Acquired Immune Deficiency Syndrome (AIDS), and hepatitis $\mathrm{C}$ virus (HCV) are among the major challenges to public health in the world. Both are RNA viruses and share common transmission routes, including parenteral, sexual and vertical. This epidemiological similarity results in a high prevalence of $\mathrm{HIV} / \mathrm{HCV}$ co-infection and represents an important factor of morbidity and mortality for the individuals affected. ${ }^{1-4}$

Liver diseases are one of the most frequent causes (9\%) of hospitalization and death in HIV infected patients, with co-infection with HCV an important cofactor for worsening the clinical picture. ${ }^{3,5}$ The prevalence of $\mathrm{HIV} / \mathrm{HCV}$ co-infection varies widely in different pop- ulations, according to the associated risk factors, distinct epidemiological characteristics and methodological differences.

$\mathrm{HIV} / \mathrm{HCV}$ co-infection significantly alters the clinical course of these infections and is associated with unfavorable outcomes. In addition to liver damage, HCV enhances the activation of the immune system, chronic inflammation, and increased cardiovascular risk, kidney diseases and cancer. Furthermore, it can slow down the reconstitution of the immune system after highly active anti-retroviral treatment (HAART), and increase the risk of progression to AIDS. ${ }^{3,5,6}$ Concomitant treatment of these viruses may cause drug interaction between HAART and direct-acting antiviral agents (DAA), used in the treatment of HCV, increasing liver damage by up to three 
times. ${ }^{5,7,8}$ Furthermore, co-infected patients have lower $\mathrm{HCV}$ clearance and greater viral load, and thus more rapid progression of liver disease compared to HIV patients that are not co-infected. ${ }^{1,4,9-11}$ HIV patients classified as rapid progressors have a higher HCV viral load than longterm progressors, suggesting that immunological and/or genetic factors also contribute to control of viremia in both viruses. ${ }^{12}$

Given the complexity of treatment in co-infected patients, it is necessary to identify HCV co-infection in individuals with HIV early in order to establish therapeutic measures and even primary prevention that alters the progression to chronicity. In such patients, treatment for HCV with DAA should be prioritized. ${ }^{5,13}$

The present study analyzed some epidemiological factors involved in the co-infection of $\mathrm{HIV} / \mathrm{HCV}$ in patients from Curitiba and the metropolitan region under monitoring at the Infectious and Parasitic Diseases Outpatient Clinic of the Hospital de Clínicas da Universidade Federal do paraná (HC/UFPR) in order to determine the prevalence and associated risk factors.

\section{Methods}

\section{Patients and clinical data}

303 HIV positive individuals of both sexes were analyzed during monitoring at the Infectious and Parasitic Diseases Outpatient Clinic of the HC/UFPR from April 2008 to March 2009.

The clinical and epidemiological data were obtained during medical visits by filling in a questionnaire on the risk factors associated with HIV acquisition, and through a retrospective analysis of medical records. The following variables were analyzed: age, sex, date of first positive serology for HIV, possible form of acquisition of the virus and associated risk factors such as use of injectable drugs, number of sexual relations and history of blood transfusion and/or blood products.

This study was approved by the Ethics Committee for Research on Human Beings (CEP) at the HC/UFPR under $n^{\circ}$ CEP/HC 1409.074/2007-04.

\section{Collection of blood and laboratory analysis}

The patients treated at the Infectious and Parasitic Diseases Outpatient Clinic of the HC/UFPR in Curitiba, with HIV positivity determined according to the protocol of the National Coordination of STD/AIDS of the Ministry of Health (CNDST/AIDS-MS), were contacted and, after proper clarification and signing of the informed consent (IC) form, $5 \mathrm{~mL}$ of venous blood with anticoagulant was collected from each patient. After centrifuga- tion, the serum was suitably separated, aliquoted and stored at $-80^{\circ} \mathrm{C}$ until tested for the presence of anti-HCV antibodies.

Anti-HCV antibodies were determined by enzyme immunoassay with micro chemiluminescence (MCL), using the Architect ${ }^{\circledR}$ (Abbott, USA) commercial systems of the clinical analyses service of the HC/UFPR, according to manufacturer's instructions.

\section{Statistical analysis}

The data collected and results obtained were tabulated in an Excel spreadsheet and comparisons between groups were performed using the two-tailed Fisher's exact test, Student's t-test or chi-square test. The odds ratio value and confidence interval of $95 \%$ were calculated when appropriate. $\mathrm{P}$-values $<0.05$ were considered significant.

\section{RESULTS}

The results of the characterization of the sample are presented in Table 1. Among the 303 HIV patients studied, $153(50.5 \%)$ were male and 150 patients (49.5\%) were female, with a mean age of 41.2 years (18 to 73 years). In relation to the predominant ancestry, 289 (95.4\%) were Euro-Brazilians and 14 (4.6\%) were Afro-Brazilians.

$39 / 303$ patients were identified (12.9\%) as seropositive for $\mathrm{HCV}$, a total of $25 / 39$ (64.1\%) of whom were male and $14 / 39$ patients $(35.9 \%)$ female, with a mean age of 44.5 (24-66 years); 37 (94.9\%) were Euro-Brazilians and 2 (5.1\%) Afro-Brazilians. Among the remaining 264 (87.1\%) HIV patients, 139/264 (52.7\%) were female and 125/264 (47.3\%) were male, with a mean age of 40.7 years and variation of 18 to 73 years. The prevalence of HCV infection was significantly higher in HIV patients $(12.9 \%)$ than in the general population of Curitiba $(0.15 \%)^{14}\left(\mathrm{p}^{<10^{-6}}\right.$, $\mathrm{OR}=100.4$; $95 \mathrm{CI}=13.7-734.9$ ).

The age and descent were similar in the two groups of HIV and HIV/HCV patients. In relation to sex, women represented $52.7 \%$ of cases in patients not co-infected and $35.9 \%$ in co-infected patients, suggesting a trend, albeit not significant $(\mathrm{p}=0.059)$, towards a higher frequency of co-infected males.

Only 193 (63.7\%) of the 303 patients analyzed informed their supposed route of HIV infection. Therefore, in $110(36.3 \%)$ of patients it was not possible to trace the route of infection of the virus. The co-infected patients differed from those not co-infected in relation to the frequency of sexual transmission and parenteral routes $(\mathrm{p}=0.02$, $\mathrm{OR}=0.2,95 \% \mathrm{CI}=0.1-0.7$ ), with the sexual route most frequent among $\mathrm{HIV} / \mathrm{HCV}$ - and parenteral among those with $\mathrm{HIV} / \mathrm{HCV}$. Regarding injectable drug use $\left(\mathrm{p}^{<10^{-6}}, \mathrm{OR}=11.1\right.$, 
TABLE 1 Characterization of the sample.

\begin{tabular}{|c|c|c|c|c|}
\hline & HIV n=264 (\%) & HIV/HCV n=39 (\%) & $\mathbf{p}$ & OR (CI95\%) \\
\hline Descent & & & n.s. ${ }^{2}$ & \\
\hline Euro-Brazilians & $252(95,5)$ & $37(94,9)$ & & \\
\hline Afro-Brazilians & $12(4.5)$ & $2(5.1)$ & & \\
\hline Gender & & & n.s. ${ }^{2}$ & \\
\hline Female & $139(52.7)$ & $14(35.9)$ & & \\
\hline Male & $125(47.3)$ & $25(64.1)$ & & \\
\hline \multicolumn{5}{|l|}{ Age } \\
\hline Mean $( \pm$ SD3 $)$ & $40.7( \pm 11.0)$ & $44.5( \pm 11.4)$ & n.s. ${ }^{2}$ & \\
\hline Median (min-max) & $39.4(18-73)$ & $41.7(24-66)$ & & \\
\hline Progression time & & & n.s. ${ }^{2}$ & \\
\hline$<2$ years & $131(49.6)$ & $13(33.3)$ & & \\
\hline 2-5 years & $45(17.0)$ & $11(28.2)$ & & \\
\hline $6-10$ years & $33(12.5)$ & $6(15.4)$ & & \\
\hline$\geq 10$ years & $6(2.3)$ & $0(0)$ & & \\
\hline N.I. ${ }^{1}$ & $49(18.6)$ & $9(23.1)$ & & \\
\hline Risk group & & & 0.02 & $0.21(0.06-0.71)$ \\
\hline Sexual & $120(45.4)$ & $9(23.1)$ & & \\
\hline Sexual/parenteral ${ }^{4}$ & $14(5.3)$ & $5(12.8)$ & & \\
\hline Parenteral $^{4}$ & $33(12.5)$ & $12(30.8)$ & & \\
\hline N.I. ${ }^{1}$ & $97(36.7)$ & $13(33.3)$ & & \\
\hline Transmission routes & & & 0.01 & $0.27(0.10-0.74)$ \\
\hline 1 route & $152(57.6)$ & $19(48.7)$ & & \\
\hline 2 routes & $13(4.9)$ & $7(17.9)$ & & \\
\hline More than 2 routes & $2(0.8)$ & $0(0)$ & & \\
\hline N.I. ${ }^{1}$ & $97(36.7)$ & $13(33.3)$ & & \\
\hline Risk group for IDU ${ }^{5}$ & & & $<10^{-6}$ & $11.12(4.46-27.72)$ \\
\hline IDU & $21(7.9)$ & $16(41.0)$ & & \\
\hline Non-IDU & $146(55.3)$ & $10(25.6)$ & & \\
\hline N.I. ${ }^{1}$ & $97(36.7)$ & $13(1.4)$ & & \\
\hline
\end{tabular}

95CI=4.5-27.7), this was significantly higher among coinfected patients (61.5\%) than those not co-infected (12.6\%) and also in relation to the number of transmission routes to which they reported being exposed $(\mathrm{p}=0.01, \mathrm{OR}=0.3$, 95CI=0.1-0.7).

Among patients not co-infected, 167/264 (63.3\%) informed the supposed route of infection. 15/167 (9.0\%) of these cases had two or more overlapping transmission routes, 120/167 (71.9\%) reported sexual contact only, $19 / 167$ (11.4\%) reported the parenteral route by blood transfusion, and 13/167 (7.8\%) intravenous injectable drug use (IDU). Among individuals with overlapping routes, the sexual route was reported in 14/15 and the parenteral route was involved in all cases.
Among HIV patients co-infected with $\mathrm{HCV}, 26 / 39$ (66.7\%) informed the supposed route of infection. $7 / 26$ of these presented overlapping routes, 10/26 (38.5\%) reported only IDU and 9/26 (34.6\%) only the sexual route. No cases of isolated infection via transfusion were reported. Among individuals with overlapping routes, the sexual route was reported in 5/7 and the parenteral was involved in 7 cases. Therefore, the parenteral route was the most frequent among patients co-infected with $\mathrm{HIV} / \mathrm{HCV}$ $12 / 26$ (46.1\%), while the sexual transmission route was more frequent among HIV patients without co-infection 120/167 (71.9\%).

There was no difference between the route of infection between men and women and between age groups, 
both in the co-infected group and the group with HIV alone. In relation to the time for progression to AIDS, among co-infected patients, the analyses were not conclusive because the majority of the patients were unable to inform the approximate date of the start of infection.

\section{Discussion}

The prevalence indexes for HIV infection remain alarming. According to the World Health Organization (WHO), approximately $3 \%$ of the world population is infected with HIV and Brazil has one of the highest rates in South America, from 2.5 to $10 \% .^{15}$

With the introduction of HAART therapy in 1996 there was a significant decrease in mortality of individuals infected with HIV. However, in the last 10 years, despite the efficiency of this therapy, we have seen a worsening of the clinical condition of these patients in relation to liver disease, such as decompensated cirrhosis and hepatocellular carcinoma, mainly due to co-infection with HBV and HCV. These clinical symptoms have been the main cause of hospitalization, accounting for $9 \%$ of deaths among HIV infected individuals. ${ }^{16,17}$ Various strategies have been proposed for the reduction of mortality in these individuals, such as vaccination against $\mathrm{HBV}$ and optimization of HIV and HCV therapies; screening for alco- hol abuse; and diagnosis and treatment of underlying diseases, such as diabetes. ${ }^{18}$

The prevalence of HCV infection was significantly associated with HIV infection compared with the prevalence of $\mathrm{HCV}$ in the general population of Curitiba, which justifies screening for HCV in HIV patients. Co-infection with $\mathrm{HCV}$ is a major etiological cause of liver disease in HIV-infected individuals, with a negative impact on these patients. Liver damage induced by the immunosuppression caused by the presence of HIV is boosted by the presence of $\mathrm{HCV}$, which also causes chronic inflammation in the liver, leading to an increased risk of cardiovascular and kidney diseases. ${ }^{4,19}$

The co-infection rates vary widely in different populations, probably due to differences in the population groups and methodologies used (Table 2). The prevalence of co-infection varies in different populations, from $10 \%$ and possibly reaching $85 \%$ in IDU. ${ }^{1}$ In the United States and Europe, it is estimated that approximately $30 \%$ of HIV patients are co-infected with $\mathrm{HCV},{ }^{17}$ which may reach up to $95 \%$ if one considers blood as the route of transmission, both IDU as well as blood transfusion. ${ }^{20}$ In Brazil, the prevalence varies from 5 to $54 \%$ depending on the region investigated and the study design, ${ }^{21-26}$ and may reach $84 \%$ in IDU. ${ }^{21,27}$ In this study, we observed a preva-

TABLE 2 Prevalence of HCV/HIV co-infection in different Brazilian geographical regions

\begin{tabular}{|c|c|c|c|}
\hline Geographical regions & $\mathbf{N}$ & $\begin{array}{l}\text { HCV-HIV prevalence } \\
\text { (Anti-HCV) }\end{array}$ & References \\
\hline Florianópolis, SC & 99 & $53.8 \%$ & Treitinger et al., $1999^{34}$ \\
\hline São Paulo, SP & 1,457 & $17.7 \%$ & Mendes-Corrêa et al., $2001^{41}$ \\
\hline Rio de Janeiro, RJ & 238 & $8.9 \%$ & Ferraz et al., $2002^{42}$ \\
\hline Campinas, SP & 232 & $53.8 \%$ & Pavan et al., $2003^{35}$ \\
\hline Santos, SP & 495 & $36.2 \%$ & Segurado et al., $2004^{21}$ \\
\hline Londrina, PR & 784 & $21.0 \%$ & Morimoto et al., $2005^{22}$ \\
\hline Manaus, AM & 704 & $5.0 \%$ & Braga et al., $2006^{23}$ \\
\hline Porto Alegre, RS & 330 & $38.2 \%$ & Tovo et al., $2006^{25}$ \\
\hline Cuiabá, MT & 1,008 & $10.9 \%$ & Mussi et al., $2007^{26}$ \\
\hline Botucatu, SP & 150 & $14.7 \%$ & Corvino et al., $2007^{43}$ \\
\hline Belo Horizonte, MG & 824 & $9.2 \%$ & Carmo et al., $2008^{44}$ \\
\hline Belo Horizonte, MG & 300 & $15.7 \%$ & Rodrigues et al., $2008^{45}$ \\
\hline Londrina, PR & 778 & $21.0 \%$ & Reiche et al., $2008^{29}$ \\
\hline São Paulo, SP & 8,019 & $12.9 \%$ & Farias et al., $2008^{28}$ \\
\hline Recife, PE & 343 & $4.1 \%$ & Carvalho et al., $2009^{46}$ \\
\hline São Paulo, SP & 2,024 & $16.7 \%$ & Mendes-Corrêa et al., $2010^{40}$ \\
\hline Santa Maria, RS & 250 & $31.2 \%$ & Santos et al., $2010^{30}$ \\
\hline CE & 1,291 & $25.4 \%$ & Távora et al., $2013^{32}$ \\
\hline Curitiba, PR & 303 & $12.9 \%$ & Present study \\
\hline
\end{tabular}


lence of $12.9 \%$ co-infection with HCV among patients monitored at the Infectious and Parasitic Diseases Outpatient Clinic at the HC/UFPR in Curitiba. This rate was similar to that found in São Paulo by Farias et al. ${ }^{28}$ but lower than that observed in patients in Londrina (PR) by Reich et al. ${ }^{29}(21 \%)$ and in Santa Maria (RS) by Santos et al. ${ }^{30}(31.2 \%)$. The prevalence of co-infection with HCV observed in Curitiba was lower than those reported in Eastern European countries and the United States, which ranges from $20-40 \% .5,18$

Although some authors, such as Greub et al. ${ }^{7}$ and Lakus et al. ${ }^{1}$ report rapid progression to AIDS in the presence of co-infection with HIV/HCV, this evidence was not found in our study, possibly due to the limited number of sampling of co-infected cases (39 cases). However, a meta-analysis by Chen et al. characterized that the increased mortality in these patients was not associated with AIDS defining events. ${ }^{19}$

According to the Ministry of Health, the Brazilian profile of HIV infection in 2012 was 1.7 cases of men for every case in women, ${ }^{31}$ while in the present study the proportion found was 1:1. In relation to the frequency of $\mathrm{HIV} / \mathrm{HCV}$ co-infection with regard to sex, there was a greater proportion of men (64.1\%) compared to women (35.9\%) among co-infected patients. Although the difference is not significant $(\mathrm{p}=0.06)$, these data are similar to those reported by Távora et al. ${ }^{32}$ in northeastern Brazil (77.8 and 22.2\%, respectively) and Reiche et al..$^{29}$ (71.1 and $28.9 \%$, respectively) in Londrina (PR).

The descent profile characterized in our study is directly related to the profile of the population of the metropolitan region of Curitiba, according to the last census by the Brazilian Census Bureau (IBGE - Instituto Brasileiro de Geografia e Estatística), ${ }^{33}$ with a higher frequency of Euro-Brazilian individuals.

Considering the risk factors associated with $\mathrm{HCV}$ transmission, the parenteral route was reported in $46.1 \%$ of co-infected patients HIV/HCV who reported a single route of infection. This frequency increased significantly $(65.4 \%)$ when considering reports involving this associated with other routes of transmission. These findings corroborate the results obtained in other studies in Bra$\mathrm{zil}^{34,35}$ and other countries, with data indicating a frequency up to $75 \%{ }^{4,5}$ This is due to the fact that it is often not possible to state which of the routes was responsible for transmission since these individuals also had sexual contact as an associated risk factor. Although the parenteral route is the most frequent in co-infection, in 34.6\% $(9 / 26)$ of the cases the sexual route was the only route of infection reported. When multiple transmission routes were considered, the sexual route was involved in 53.8\% $(14 / 26)$ of cases. These data indicate that the sexual route is indeed an important route of transmission for $\mathrm{HCV}$, a fact corroborated by other authors in Brazil and the United States. ${ }^{6,15}$ Some studies, such as those by Vandelli et al., Bradshaw et al. and Witt et al., ${ }^{36-38}$ also reported the importance of this route. This fact has been the subject of discussion in the literature, with studies indicating the importance of this route mainly among men who have sex with men that do not use drugs. ${ }^{5,38,39}$

The successful treatment of co-infection has reduced the morbidity and mortality of these patients, whose priority treatment should be for HCV. ${ }^{18}$ However, reports from different regions of the world have shown that only $30 \%$ of co-infected patients are eligible for standard therapy with pegylated interferon and ribavirin for treatment of $\mathrm{HCV}^{40}$ and, in some cases, the choice of HAART therapy for the treatment of HIV and DAA therapy for HCV treatment will depend on the patient's response and the possible interactions between the drugs. This fact justifies the need for screening of co-infection with the HCV virus in HIV patients. The presence or absence of co-infection with $\mathrm{HCV}$ is crucial to the definition of treatment strategies, the choice of drugs and initiation of therapy that will directly impact the clinical progression and prognosis.

\section{Conclusion}

The prevalence of HCV infection in HIV patients in Curitiba is $12.9 \%$, significantly higher than that found in the general population, which justifies the need for HCV screening in HIV patients. The parenteral route of transmission is the most prevalent in co-infected patients (46.1\%), but the sexual route is also an important portion of the cases (34.6\%). In HIV patients not co-infected with HCV, the most prevalent route was sexual, in $71.9 \%$ of the cases.

\section{Funding agency}

Coordenação de Aperfeiçoamento de Pessoal de Nível Superior (CAPES) and Fundação Araucária/PPSUS.

\section{AcKnowledgments}

The authors gratefully acknowledge the participation and collaboration of patients and the staff at Hospital de Clínicas, Universidade Federal do Paraná.

\section{Resumo}

Soroprevalência de marcadores do vírus da hepatite $\mathrm{C}$ (HCV) em pacientes infectados com HIV de Curitiba e Região Metropolitana 
Objetivo: verificar a prevalência e caracterizar fatores epidemiológicos associados à coinfecção por $\mathrm{HCV}$ em pacientes HIV+ de Curitiba e Região Metropolitana.

Métodos: estudo envolvendo 303 pacientes HIV+, com idade média de 41,2 anos (18-73); 50,5\% homens; acompanhados no Hospital de Clínicas da Universidade Federal do Paraná, entre abril de 2008 e março de 2009. Os dados clínico-epidemiológicos foram obtidos por meio de questionários e análise retrospectiva dos prontuários. Os anticorpos anti-HCV foram detectados por ensaio imunoenzimático quimioluminescente.

Resultados: dos pacientes HIV+, $12,9 \%$ apresentaram sorologia positiva para o $\mathrm{HCV}$, sendo $64,1 \%$ homens e $35,9 \%$ mulheres, com idade média de 44,5 anos (24-66). A frequência nos homens foi de $16,7 \%$, e nas mulheres, $9,1 \%$ $(\mathrm{p}=0,06)$. A prevalência do HCV foi significativamente associada à infecção por HIV quando comparada à população geral $\left(\mathrm{p}<10^{-6}\right.$, OR=100,4; IC95\%=13,7-734,9). A via de transmissão parenteral foi a mais frequente entre os coinfectados $(46,1 \%)$, e a sexual, a mais frequente entre os não coinfectados $(71,8 \%)(\mathrm{p}=0,02, \mathrm{OR}=0,2 ; \mathrm{IC} 95 \%=0,1$ $0,7)$. A frequência de usuários de drogas injetáveis foi maior entre os coinfectados $(61,5 \%)$ do que entre os não coinfectados $(12,6 \%)\left(\mathrm{p}^{<10^{-6}}\right.$, OR=11,1; IC95\%=4,5-27,7). Conclusões: a prevalência da infecção por HCV nos pacientes HIV+ é de $12,9 \%, 88$ vezes maior que a infecção na população geral de Curitiba. A via de transmissão mais frequente entre os coinfectados foi a parenteral, porém, a via sexual também é representativa para a transmissão do $\operatorname{HCV}(34,6 \%)$.

Palavras-chave: HIV, síndrome de imunodeficiência adquirida, coinfecção, hepatite $\mathrm{C}$.

\section{References}

1. Laskus T, Kibler K V, Chmielewski M, Wilkinson J, Adair D, Horban A, et al. Effect of hepatitis C infection on HIV-induced apoptosis. PLoS One. 2013; 8(10):e75921.

2. Soriano V, Vispo E, Labarga P, Medrano J, Barreiro P. Viral hepatitis and HIV co-infection. Antiviral Res. 2010; 85(1):303-15.

3. Kim AY, Onofrey S, Church DR. An epidemiologic update on hepatitis C infection in persons living with or at risk of HIV infection. J Infect Dis. 2013; 207(Suppl 1):S1-6.

4. Operskalski E a, Kovacs A. HIV/HCV co-infection: pathogenesis, clinical complications, treatment, and new therapeutic technologies. Curr HIV/ AIDS Rep. 2011; 8(1):12-22.

5. Soriano V, Vispo E, Fernandez-Montero JV, Labarga P, Barreiro P. Update on HIV/HCV coinfection. Curr HIV/AIDS Rep. 2013; 10(3):226-34.

6. Zeremski M, Martinez AD, Talal AH. Management of hepatitis $C$ virus in HIV-infected patients in the era of direct-acting antivirals. Clin Infect Dis 2013; 58(6):880-2.

7. Greub G, Ledergerber B, Battegay M, Grob P, Perrin L, Furrer H, et al. Clinical progression, survival, and immune recovery during antiretroviral therapy in patients with HIV-1 and hepatitis C virus coinfection: the Swiss HIV Cohort Study. Lancet. 2000; 356(9244):1800-5.
8. Mendes-Corrêa MCJ, Barone AA, Cavalheiro NP, Tengan FM, Guastini C Prevalence of hepatitis B and C in the sera of patients with HIV infection in São Paulo, Brazil. Rev Inst Med Trop São Paulo. 2000; 42(2):81-5.

9. Aranzabal L, Casado JL, Moya J, Quereda C, Diz S, Moreno A, et al. Influence of liver fibrosis on highly active antiretroviral therapy-associated hepatotoxicity in patients with HIV and hepatitis $\mathrm{C}$ virus coinfection. Clin Infect Dis. 2005; 40(4):588-93.

10. Martín-Carbonero L, Benhamou Y, Puoti M, Berenguer J, Mallolas J, Quereda $\mathrm{C}$, et al. Incidence and predictors of severe liver fibrosis in human immunodeficiency virus-infected patients with chronic hepatitis C: a European collaborative study. Clin Infect Dis. 2004; 38(1):128-33.

11. Sulkowski MS. Viral hepatitis and HIV coinfection. J Hepatol. 2008; 48(2):353 67.

12. Thibault V, Candotti D, Autran B, Cahour A, Agut H; French ALT Study Group. Hepatitis $C$ virus infection in long-term nonprogressor HIV-1infected subjects. J Acquir Immune Defic Syndr. 2002; 29(2):204-6.

13. Labarga P, Soriano V, Vispo ME, Pinilla J, Martin-Carbonero L, Castellares $\mathrm{C}$, et al. Hepatotoxicity of antiretroviral drugs is reduced after successful treatment of chronic hepatitis C in HIV-infected patients. J Infect Dis. 2007; 196(5):670-6.

14. De Moraes Braga AC, Reason IJM, Maluf ECP, Vieira ER. Leprosy and confinement due to leprosy show high association with hepatitis $\mathrm{C}$ in Southern Brazil. Acta Trop. 2006; 97(1):88-93.

15. Martins T, Narciso-Schiavon JL, Schiavon LL. Epidemiologia da infecção pelo vírus da hepatite C. Rev Assoc Med Bras. 2011; 57(1):107-12.

16. RuppiK M, Ledergerber B, Richenbach $M$. Changing patterns of cause of death in the Swiss HIV Cohort Study (SHCS) 2005-2009. 18th CROL. Boston, 2011.

17. Puoti M, Moioli M, Travi G, Rossotti R. The burden of liver disease in HIV infected patients. Semin Liver Dis. 2012; 32(2):103-13.

18. Puoti M, Rossotti R, Travi G, Panzeri C, Morreale M, Chiari E, et al. Optimizing treatment in HIV/HCV coinfection. Dig Liver Dis. 2013; 45(Suppl 5):S355-62.

19. Chen T-Y, Ding EL, Seage Iii GR, Kim AY. Meta-analysis: increased mortality associated with hepatitis C in HIV-infected persons is unrelated to HIV disease progression. Clin Infect Dis. 2009; 49(10):1605-15.

20. Alter MJ. Epidemiology of viral hepatitis and HIV co-infection. J Hepatol. 2006; 44(1 Suppl):S6-9.

21. Segurado AC, Braga P, Etzel A, Cardoso MR. Hepatitis C virus coinfection in a cohort of HIV-infected individuals from Santos, Brazil: seroprevalence and associated factors. AIDS Patient Care STDS. 2004; 18(3):135-43.

22. Morimoto HK, Caterino-De-Araujo A, Morimoto AA, Reiche EM V, Ueda LT, Matsuo T, et al. Seroprevalence and risk factors for human T cell lymphotropic virus type 1 and 2 infection in human immunodeficiency virus-infected patients attending AIDS referral center health units in Londrina and other communities in Paraná, Brazil. AIDS Res Hum Retroviruses. 2005; 21(4):256-62.

23. Braga WSM, da Costa Castilho M, dos Santos IC, Moura MA, Segurado AC, et al. Low prevalence of hepatitis B virus, hepatitis D virus and hepatitis C virus among patients with human immunodeficiency virus or acquired immunodeficiency syndrome in the Brazilian Amazon basin. Rev Soc Bras Med Trop. 2006; 39(6):519-22.

24. Silva ACM, Barone AA. Risk factors for HIV infection among patients infected with hepatitis C. Rev Saúde Pública. 2006; 40(3):482-8.

25. Tovo CV, Santos DE, Mattos AZ, Almeida PRL, Mattos AA, Santos BR Prevalência ambulatorial em um hospital geral de marcadores para hepatites B e C em pacientes com infecção pelo vírus da imunodeficiência humana. Arq Gastroenterol. 2006; 43(2):73-6.

26. Mussi AD, Pereira RA, Corrêa e Silva VA, Martins RM, Souto FJ. Epidemiological aspects of hepatitis $\mathrm{C}$ virus infection among HIV-infected individuals in Mato Grosso State, Central Brazil. Acta Trop. 2007; 104(23):116-21.

27. Marchesini AM, Prá-Baldi ZP, Mesquita F, Bueno R, Buchalla CM. Hepatitis $\mathrm{B}$ and $\mathrm{C}$ among injecting drug users living with HIV in São Paulo, Brazil Rev Saúde Pública. 2007; 41(Suppl 2):57-63.

28. Farias N, Tancredi MV, Wolffenbüttel K, Tayra A. Characteristics from persons and factors associated to HIV-seropositivity at the São Paulo State testing \& counseling sites, 2000 to 2007. Bol Epidemiológico Paulista. 2008; 5(60). Available at: http://www.cve.saude.sp.gov.br/agencia/bepa60_hiv.htm.

29. Reiche EMV, Bonametti AM, Morimoto HK, Morimoto AA, Wiechemann SL, Matsuo T, et al. Epidemiological, immunological and virological characteristics, and disease progression of HIV-1/HCV-co-infected patients from a southern Brazilian population. Int J Mol Med. 2008; 21(3):387-95. 
30. Santos KF, Vieira TB, Beck ST, Leal DBR. Alterações laboratoriais encontradas em indivíduos co-infectados pelo vírus da imunodeficiência humana (HIV) pelo vírus da hepatite C (HCV). Rev Bras Análises Clínicas. 2010; 42(1):21-4

31. Ministério da Saúde. Boletim Epidemiológico HIV AIDS; 2013. Available at: http:/www.aids.gov.br/sites/default/files/anexos/publicacao/2013/55559/_p_ boletim_2013_internet_pdf_P_51315.pdf

32. Távora LG, Hyppolito EB, Cruz JN, Portela NM, Pereira SM, Veras CM Hepatitis B, C and HIV co-infections seroprevalence in a northeast Brazilian center. Arq Gastroenterol. 2013; 50(4):277-80.

33. IBGE. Instituto Brasileiro de Geografia e Estatística. Censo Demográfico; 2010 .

34. Treitinger A, Spada C, Silva EL, Miranda AF, Oliveira OV, Silveira MV, et al. Prevalence of serologic markers of HBV and HCV Infection in HIV-1 Seropositive Patients in Florianópolis, Brazil. Braz J Infect Dis. 1999; 3(1):1-5.

35. Pavan MHP, Aoki FH, Monteiro DT, Gonçales NSL, Escanhoela CAF, Gonçales Júnior FL. Viral hepatitis in patients infected with human immunodeficiency virus. Braz J Infect Dis. 2003; 7(4):253-61.

36. Vandelli C, Renzo F, Romanò L, Tisminetzky S, De Palma M, Stroffolini T, et al. Lack of evidence of sexual transmission of hepatitis $\mathrm{C}$ among monogamous couples: results of a 10-year prospective follow-up study. Am J Gastroenterol. 2004; 99(5):855-9.

37. Bradshaw D, Matthews G, Danta M. Sexually transmitted hepatitis C infection: the new epidemic in MSM? Curr Opin Infect Dis. 2013; 26(1):66-72.

38. Witt MD, Seaberg EC, Darilay A, Young S, Badri S, Rinaldo CR, et al. Incident hepatitis $\mathrm{C}$ virus infection in men who have sex with men: a prospective cohort analysis, 1984-2011. Clin Infect Dis. 2013; 57(1):77-84.
39. Zocratto KBF, Caiaffa WT, Proietti FA, Proietti ABC, Mingoti SA, Ribeiro GJC, et al. HCV and HIV infection and co-infection: injecting drug use and sexual behavior, AjUDE-Brasil I Project. Cad Saúde Pública. 2006; 22(4):839-48.

40. Mendes-Corrêa MC, Martins LG, Tenore S, Leite OH, Leite AG, Cavalcante $\mathrm{AJ}$, et al. Barriers to treatment of hepatitis $\mathrm{C}$ in $\mathrm{HIV} / \mathrm{HCV}$ coinfected adults in Brazil. Braz J Infect Dis. 2010; 14(3):237-41.

41. Mendes-Corrêa MC, Barone AA, Guastini C. Hepatitis C virus seroprevalence and risk factors among patients with HIV infection. Rev Inst Med Trop São Paulo. 2001; 43(1):15-9.

42. Ferraz GGS, Menezes JA, Gazineo JLD, Passoni LFC, Lessa MPM, Pinto PTA, et al. Prevalência de Infecção pelos vírus "B" e "C" da Hepatite (HBV e HCV) em pacientes com infecção pelo vírus B e C da Imunodeficiência Humana (HIV). Rev Médica HFSE. 2002; 36(1). Available at: http://www.hse.rj.saude. gov.br/profissional/revista/36/hepat.asp.

43. Corvino SM, Henriques RMS, Grotto RMT, Pardini MIMC. Co-infecção HIV/HCV em pacientes de Botucatu e região. Rev Bras Epidemiol. 2007; 10(4):537-43.

44. Carmo RA, Guimarães MD, Moura AS, Neiva AM, Versiani JB, Lima LV, et al The influence of HCV coinfection on clinical, immunological and virological responses to HAART in HIV-patients. Braz J Infect Dis. 2008; 12(3):173-9.

45. Rodrigues Mda C, Viotti JB, Braga RF, Lourenço LFS, Antunes CM, Lambertucci JR. HIV/HCV coinfection in Infectious Disease Units in Mozambique and Brazil: a comparative study. Rev Soc Bras Med Trop. 2008; 415():518.

46. Carvalho FH, Coêlho MR, Vilella Tde A, Silva JL, Melo HR. HIV/HCV coinfection at an university hospital in Recife, Brazil. Rev Saúde Pública. 2009; 43(1):133-9. 